\title{
Analisis Pendapatan Usaha Gula Aren Di Desa Buntu Pema Kecamatan Curio Kabupaten Enrekang
}

\author{
Analysis of Sugar Business Income In Buntu Pema Village, Curio District, Enrekang District
}

\author{
Irmayani $^{{ }^{*}}$, Irna Sari ${ }^{1}$, A.Erna Sriwahyuningsih ${ }^{1}$ \\ "Email: irmaumpar@yahoo.co.id \\ ${ }^{1}$ Program Studi Agribisnis, Fak. Pertanian, Peternakan dan Perikanan, Universitas Muhammadiyah Parepare
}

Diterima: 22 Mei 2021 / Disetujui: 02 Agustus 2021

\begin{abstract}
ABSTRAK
Penelitian ini bertujuan untuk mengetahui pendapatan usaha gula aren di Desa Buntu Pema Kecamatan Curio Kabupaten Enrekang. Metode penelitian yang digunakan adalah metode kuantitatif yang bertujuan untuk mendapatkan gambaran yang mewakili suatu daerah dengan benar, dan untuk menjangkau fakta yang terjadi di lapangan melalui kunjungan dan wawancara langsung, sehingga diperoleh gambaran secara keseluruhan mengenai pendapatan ekonomi rumahtanggga pengrajin Aren di Desa Buntu Pema Kecamatan Curio Kabupaten Enrekang berdasarkan berdasarkan data yang diperoleh dari rumahtangga petani. Hasil penelitian menunjukkan Total pendapatan gula aren di daerah Buntu Pema adalah Rp.149.444.700/produksi. Pendapatan gula aren di Daerah Buntu Pema adalah Rp. 2.532.560 selama selama satu kali produksi.Hasil rata-rata pendapatan petani responden cukup besar untuk digunakan menutupi kegutuhan hidup dan menunjang keuangan rumah tangga petani dikala tepuruknya harga komoditi pertanian utama petani sampel di daerah penelitian.Nilai revenue cost ratio (R/C49-ratio) adalah sebesar 1,98 menunjukkan bahwa $\mathrm{R} / \mathrm{C}>1$ berarti usaha layak untuk dijalankan. Atau denga kata lain pendapatan lebih besar dari total biaya yang dikeluarkan maka usaha gula aren di Desa Buntu Pema di Kecamatan Curio Kabupaten Enrekang layak untuk di jalankan.
\end{abstract}

Kata Kunci : Kelayakan Usaha, Gula Aren, Enrekang

\begin{abstract}
This study aims to determine the income of palm sugar business in Buntu Pema Village, Curio District, Enrekang Regency. The research method used is a quantitative method that aims to get a picture that represents an area correctly, and to reach the facts that occur in the field through visits and direct interviews, so that an overall picture of the household income of Aren craftsmen in the dead-end village Pema Curiokabupati is obtained enrekang based on data obtained from farmer households. The results showed that the total income of palm sugar in the Buntu Pema area was IDR 149,444,700 / production. Palm sugar income in the Buntu Pema area is Rp. 2,532,560 during one production. The average yield of the respondent's farmers' income is large enough to be used to cover the necessities of life and to support farmer household finances when the prices of the main agricultural commodities of the sample farmers in the study area have fallen. The value of revenue cost ratio ( $R$ / C49-ratio) is 1.98 indicating that $R / C>1$ means the business is feasible to run. Or in other words, the income is greater than the total costs incurred, the palm sugar business in Buntu Pema Village in Curio District, Enrekang Regency is feasible to run.
\end{abstract}

Keywords: Feasibility, Plam Sugar, Enrekang

(c) (7) This work is licensed under Creative Commons Attribution License 4.0 CC-BY International license

\section{A. PENDAHULUAN}

Indonesia merupakan salah satu

Negara yang kaya akan sumber daya alam
(SDA), Baik flora, fauna dan tanah yang begitu amat subur. Pemanfaatan hutan sebagai bahagian dari sektor agribisnis 
dapat memberi manfaat langsung dan tidak langsung.Manfaat langsung adalah nilai ekonomi langsung yang diberikan kepada produk-produk yang dipanen secara langsung dapat dibagi menjadi nilai kegunaan konsumtif untuk barang yang dipergunakan secara lokal dan nilai kegunaan produktif untuk barang yang dijual di pasar.Sedangkan manfaat tidak langsung yang diberikan untuk aspek-aspek keanekaragaman hayati seperti halnya proses-proses lingkungan dan jasa.Salah satu pemanfaatan hasil hutan bukan kayu adalah pemanfaatan pohon aren.

Aren (Arenga Pinnata MERR) adalah tanaman perkebunan yang sangat potensial untuk mengatasi kekurangan pangan. Tanaman ini mudah beradaptasi pada berbagai agroklimat, mulai dari daratan rendah hingga ketinggian $1400 \mathrm{~m}$ di atas permukaan laut.

Gula aren merupakan produk dari tanaman aren. Bahan baku yang berasal dari tanaman aren dinamakan nira. Nira adalah cairan manis yang diperoleh dari tandan tanaman aren. Gula aren bisa dijadikan sebaga bahan tambahan dalam produk pangan seperti pada pembuatan kecap dan dodol, bahan tambahan atau penyedap rasa pada olahan makanan seperti aneka kue, kolak, dan olahan makanan lainnya, serta bahan pemanis pada minuman seperti bandrek, bajigur, kopi, dan lainnya. Gula aren memiliki kekhasan tersendiri apabila dibandingkan dengan gula dari sumber yang lain. Kekhasan produk ini antara lain, lebih mudah larut, keadaannya kering dan bersih serta mempunyai aroma khas. Kekhasan tersebut yang menyebabkan gula aren banyak digunakan untuk membuat kue, kecap dan produk pangan lainnya (Aliudin 2010). Menurut Rumokoi (2010) kelebihan gula aren dibandingkan gula lain berdasarkan komposisi kimia yakni kandungan sukrosanya lebih tinggi yaitu 84,81persen dibandingkan gula kelapa 71,89 persen dan gula siwalan 76,86 persen, sehingga gula aren mampu menyediakan energi yang lebih tinggi daripada gula kelapa dan gula siwalan. Berdasarkan kandungan gizinya, dibandingkan gula lain, gula aren mengandung protein dan fosfor yang lebih tinggi daripada gula kelapa dan gula siwalan.Gula aren juga mengandung lemak yang rendah dibandingkan dengan gula yang berasal dari gula kelapa dan gula siwalan. Kandungan protein yang tinggi dan kadar lemak yang rendah, menunjukkan bahwa gula aren lebih baik untuk dikonsumsi dibandingkan dengan gula yang berasal dari kelapa dan siwalan, terutama manfaatnya bagi kesehatan tubuh.

Aren adalah jenis tanaman tahunan, berukuran besar, berbentuk pohon soliter 
tinggi hingga $12 \mathrm{~m}$, diameter setinggi dada hingga $60 \mathrm{~cm}$. Pohon aren dapat tumbuh tinggi dengan diameter batang sampai 65 $\mathrm{cm}$ dan tinggi $15 \mathrm{~m}$ bahkan mencapai $20 \mathrm{~m}$ dengan tajuk daun yang menjulang di atas batang. Tanaman aren tumbuh dengan baik pada ketinggian 500-1200 $\mathrm{m}$ di atas permukaan laut.Aren telah lebih 200 tahun dibudidayakan khususnya di Indonesia, untuk dimanfaatkan tepung dan gulanya.Karakter pohon aren juga lebih luwes dan kuat dari pada tebu.Aren biasa tumbuh di lahan kritis serta kontur lahan datar atau miring sekaligus mampu mengonservasi lahan gundul.Akar memiliki kemampuan yaitu mengikat akar dengan baik sehingga dapat ditanam di daerah yang relatif kering. Aren juga tidak memerlukan perawatan khusus atau pemupukan karena pada dasarnya merupakan tanaman hutan sehingga tidak perlu pupuk dan irigasi.

Produk utama tanaman aren di Desa Buntu Pema KecamatanCurio Kabupaten Enrekang adalah nira. Prospek pengembangan tanaman aren mendukung kebutuhan bioetanol di Indonesia adalah gula aren maupun minuman ringan, cuka dan alkohol. Gula aren atau bisa juga disebut gula merah menjadi penghasilan tambahan bagi masyarakat di Desa Buntu Pema KecamatanCurio Kabupaten Enrekang. Selain bertani dan beternak mereka cekatan mengubah tuak manis menjadi gula merah, dimana hasil penjualan gula merah ini cukup mampu memenuhi kebutuhan sehari-hari keluarga mereka.

\section{Desa Buntu Pema kecamatan Curio} Kabupaten Enrekang merupakan suatu desa yang hamper semua penduduknya berprofesi sebagai petani yang memannfaatkan lahan perkebunan yang salah satunya adalah pohon aren. Petani usaha aren yang mengolah menjadi produk yang salah satunya adalah gula aren sebagai sumber ekonomi sehingga dari data yang diperoleh ada sekitar 170 orang atau 50,22\% dengan 40 kepalah keluarga yang berprofesi sebagai petani (RPJM Desa buntu pema, 2020). Untuk mengetahui seberapa besar pendapatan yang diterima oleh masyarakat di Kabupaten enrekang khususnya di Desa buntu pema yang mengolah aren sebagai sumber penghasilan atau untuk memenuhi kebutuhan sehari-hari.

Tabel 1. Produksi Gula Aren Dalam 3 Tahun Terakhir di Kabupaten Enrekang

\begin{tabular}{cc}
\hline Tahun & Produksi(unit) \\
\hline 2017 & 13.440 unit \\
2018 & 13.600 unit \\
2019 & 13.800 unit \\
\hline \multicolumn{2}{l}{ Sumber :Kantor Dinas Pertanian Enrekang, 2018 }
\end{tabular}

Tahun 2017 jumlah produksi gula aren sebanyak 13.440 unit. kemudian tahun 2018 meningkat menjadi 13.600 unit dan pada tahun 2019 meningkat menjadi 13.800 unit. Pohon aren yang dikelola adalah warisan dari alam, tidak pernah terpikir 
menanam dengan pola perkebunan yang teratur dan dalam jumlah yang banyak.Karena masih tumbuh secara alami hingga jumlah pohon aren yang tumbuh masih jarang atau kurang dalam satu luasan tertentu, Demikian pula dengan pemeliharaan pohon aren belum dilaksanakan dengan maksimal sehingga pohon yang produktif yang disadap masih kurang.

Prospek komoditi ini semakin menjanjikan karena bahan baku untuk pembuatan gula aren ketersediaannya berlimpah dalam menunjang pengembangan industri kecil gula aren. Namun peluang pasar yang menjanjikan keuntungan besar serta didukung oleh bahan baku yang besar, belum mampu dimanfaatkan oleh industri pengolahan gula aren secara maksimal. Ada beberapa kendala yang mungkin dihadapi oleh pengrajin gula aren dalam mengembangkan usahanya.Petani gula aren tampaknya masih memiliki keterbatasan dalam permodalan, pemasaran dan teknologi yang digunakan. Lebih lanjut, seperti usaha pada bidang lain, petani gula aren juga akan dihadapkan pada .yang dihadapi tidak saja harga tetapi juga risiko untuk memperoleh nira yang disadap serta produksi.

\section{B. METODE PENELITIAN}

Metode penelitian yang digunakan adalah metode survey yang bertujuan untuk mendapatkan gambaran yang mewakili suatu daerah dengan benar, dan untuk menjangkau fakta yang terjadi di lapangan melalui kunjungan dan wawancara langsung, sehingga diperoleh gambaran secara keseluruhan mengenai pendapatan ekonomi rumahtanggga pengrajin Aren di desa buntu pema kecamatan curiokabupaten enrekang berdasarkan berdasarkan data yang diperoleh dari rumahtangga petani

\section{Populasi dan Sampel}

Penentuan lokasi dan pengambilan sampel yaitu di Desa Buntu Pema Kecamatan Curio Kabupaten Enrekang.Metode pengambilan sampel dalam penelitian ini dengan menggunakan metode Sampling Jenuh. Populasinya yaitu 20 pengrajin gula aren.

Menurut Sugiyono (2018) sampling jenuh adalah cara pengumpulan sampel dengan menjadikan seluruh anggota populasi sebagai sampel. Sedangkan dalam penelitin ini jumlah populasinya adalah 20 orang sehingga sampelnya adalah 20 orang.

\section{Teknik Pengumpulan Data}

Teknik pengumpulan data yang digunakan sebagai berikut :

a. Observasi merupakan teknik pengumpulan data yang dilakukan 
dengan mengambil secara langsung kegiatan yang oleh objek peneliti.

b. Wawancara merupakan teknik pengumpulan data yang langsung dalam bentuk tanya jawab dengan responden.

c. Quisioner yaitu pertanyaan tertulis dengan diajukan kepada responden. Dalam menggunakan quisioner, maka peneliti akan banyak mendapatkan data secara factual

\section{Analisis data}

a. Biaya

Gabungan biaya tetap dan biaya variabel disebut biaya total (total cost) yang secara umum dirumuskan sebagai berikut:

$$
\mathrm{TC}=\mathrm{FC}+\mathrm{VC}
$$

Keterangan:

TC $($ Total Cost $)=$ Total biaya produksi gula aren $(\mathrm{Rp})$

FC $($ Total Fixed Cost $)=$ Biaya tetap $(\mathrm{Rp})$

$\mathrm{VC}($ TotalVariableCost $)=$ Biaya tidak

\section{b. Penerimaan}

Penerimaan usahatani dapat diterima petani, penerimaan harus dikurangi biaya-biaya yang dikeluarkan dalam usahatani. Penerimaan usahatani adalah perkalian antara produksi yang diperoleh dengan harga jual produknya dengan menggunakan rumus sebagai berikut :

$$
\mathrm{TR}=\mathrm{Q} \cdot \mathrm{P}
$$

Keterangan:

TR $($ Total Revenue $)=$ Penerimaan usaha (Rp)

$\mathrm{Q}($ Quantity $)=$ Produk gula aren $(\mathrm{Kg})$

$\mathrm{P}($ Price $)=$ Harga jual produk gula aren $(\mathrm{Rp} / \mathrm{Kg})$

c. Pendapatan

Pendapatan adalah semua penghasilan yang diperoleh dari pihak lain sebagai tanda balas jasa yang diberikan dimana penghasilan tersebut digunakan untuk memenuhi kebutuhan keluarga atau perseorangan. Disimpulkan pendapatan adalah semua penghasilan yang diterima dari pihak lain dari kegiatan ekonomi dalam satu periode tertentu dengan menggunakan rumus sebagai berikut :

$$
\pi=\mathrm{TR}-\mathrm{TC}
$$

Keterangan:

$\Pi=$ Pendapatan usaha gula $\operatorname{aren}(\mathrm{Rp})$

TR $($ Total Revenue $)=$ Penerimaan usaha gula aren (Rp)

TC $($ Total Cost $)=$ Total biaya produksi usaha gula aren (Rp)

d. Kelayakan Usaha

Revenue Cost Ratio (R/CRasio) merupakan perbandingan antara total penerimaan dengan total biaya dengan rumus yaitu (Soekartawi, 2006).

$$
\mathrm{R} / \mathrm{C}=\mathrm{TR} / \mathrm{TC}
$$

Keterangan

$\mathrm{R} / \mathrm{C}$ Rasio= Rasio penerimaan atas biaya

$\mathrm{TR}=$ Total penerimaan $(\mathrm{Rp})$

$\mathrm{TC}=$ Total biaya $(\mathrm{Rp})$ 
Kriteria yang di gunakan dalam atau aktivitas produksi pada tingkat penentuan efesiensi usaha adalah:

a) $\mathrm{R} / \mathrm{C}>1$ berarti usaha layak untuk dijalankan

b) $\mathrm{R} / \mathrm{C}=1$ berarti usaha yang di jalankan mencapai titik impas

c) $\mathrm{R} / \mathrm{C}<1$ berarti usaha tidak layak untuk di jalankan.

\section{HASIL DAN PEMBAHASAN}

1. Hasil Analisis Pendapatan Gula Aren di Desa Buntu Pema Kecamatan Curio Kabupaten Enrekang

Dalam pembuatan gula aren ada beberapa bahan bahan yang disediakan seperti air nira, kemiri,, buah rambusa (passifolra foetida). Tapi dalam penelitian ini air nira dan buah rambusa (passifolra foetida) tidak di beli dalam pembuatan gula aren. Sehingga air nira sebagai bahan pokok tidak dimasukkan kedalam biaya tetap.

\section{a. Deskripsi besar biaya usaha Gula Aren}

Besar biaya usaha gula aren dalam penelitan ini adalah semua biaya yang digunakan dalam pembuatan gula aren. Biaya tersebut dibagi atas dua yaitu biaya tetap dan biaya variabel.

\section{b. Biaya Tetap}

Biaya tetap merupakan biaya yang dikeluarkan dalam besaran yang tetap atau stabil.Biaya tetap ini keberadaannya tidak dipengaruhi oleh adanya perubahan jumlah tertentu.Biaya tetap yang di maksudadalah biaya yang biaya penyusutan alat-alat yang digunakan saat memproduksi gula aren atau biaya yang besar kecilnya tidak tergantung pada besar kecilnya produksi, biaya tetap dalam penelitian ini adalah pajak dan penyusutan alat-alat produksi contonya yaitu wajan, spatula, ember, cetakan dan dapur kayu api.untuk lebih jelasnya maka akan dirincihkan biaya tetap tersebut pada Table 2.

Tabel 2. Deskripsi biaya Tetap yang Digunakan Oleh Responden Usaha pembuatan gula aren.

\begin{tabular}{llcc}
\hline No & $\begin{array}{c}\text { Jenis Biaya } \\
\text { Tetap }\end{array}$ & Jumlah & Rata-rata \\
\hline 1 & Pajak & 510.000 & 25.500 \\
2 & Penyusutan & 1.612 .440 & 80.622 \\
\hline & Jumlah & 2.122 .440 & 106.122 \\
\hline
\end{tabular}

Tabel 2 mendiskripsikan biaya tetap yang dikeluarkan oleh 20 orang pelaku usaha responden di Desa Buntu Pema Kecamatan Curio Kabupaten Enrekang adalah Rp. 2.122.440 atau dengan rata-rata sebesar Rp 106.122. biaya penyusutan tersebut terdiri rata-rata harga wajan $\mathrm{Rp}$ 303.500 dengan rata-rata penyusutan $\mathrm{Rp}$ 54.630 yang di gunakan untuk tempat penrebusan air nira. Rata-rata Harga spatula yaitu Rp 25.000 dengan rata-rata penyusutan yaitu Rp 4.500 yang digunakan sebagai untuk mengaduk air nira diatas wajan, rata-rata harga penyaring yaitu $\mathrm{Rp}$ 14.900 dan rata-rata penyusutan yaitu $\mathrm{Rp}$ 
2.682 yang digunakan sebagai penyaringan benda-benda asing yang tidak dikehendaki setelah air nira diendapkan dengan kapur. Rata-rata harga dapur kayu bakar yaitu Rp 85.000 dengan rata-rata penyusutan $\mathrm{Rp}$ 15.300 yang digunakan sebagai tempat pemasakan.jumlah biaya tersebut akan disesuaikan dengan berapa besar biaya yang dikeluarkan pada pengeluaran alat, masingmasing responden.

Pajak Bumi dan Bangunan adalah pungutan atas tanah dan bangunan yang muncul karena adanya keuntungan dan/atau kedudukan sosial ekonomi bagi seseorang atau badan yang memiliki suatu hak atasnya, atau memperoleh manfaat dari padanya.

Jika dilihat dari sifatnya, Pajak Bumi dan Bangunan merupakan pajak yang bersifat kebendaan. Artinya, besaran pajak terutang ditentukan dari keadaan objek yaitu bumi dan/atau bangunan. Sedangkan keadaan subjeknya tidak ikut menentukan besarnya barang.Pajak lahan pada penelitian ini dari 20 responden berjumlah $\mathrm{Rp}$ 510.000 dengan rata-rata sebesar Rp 25.500.

\section{c. Biaya variable}

Biaya variabel adalah biaya yang dikeluarkan saat memproduksi gula aren, biaya ini selalu berubah tergantung kepada besar kecilnya produksi.Dalam usaha gula aren biaya pembuatan aren meliputi air nira, kemiri, buah rambusa (Passiflora foetida) tetapi bahan yang di beli hanya kemiri dan bahan lainnya tidak dibeli. Biaya tersebut dirincihkan pada Table 3.

Tabel 3. Deskripsi Biaya Variabel yang Digunakan oleh Responden Usaha Pembuatan Gula Aren.

\begin{tabular}{llll}
\hline No & $\begin{array}{l}\text { Jenis Biaya } \\
\text { variabel }\end{array}$ & $\begin{array}{l}\text { Jumlah } \\
(\mathbf{K g})\end{array}$ & $\begin{array}{l}\text { Rata- } \\
\text { rata } \\
(\mathbf{K g})\end{array}$ \\
\hline 1 & Kemiri & 465.000 & 23.250 \\
\hline & Tabel & 3 & mendiskripsikan biaya
\end{tabular}
variabel yang dikeluarkan oleh 20 orang pelaku usaha responden di Desa Buntu Pema Kecamatan Curio Kabupaten Enrekang adalah Rp. 465.000 atau dengan rata-rata sebesar $\operatorname{Rp} 23.250$. biaya ini hanya pembelian kemiri, hal ini disebabkan bahan utama yaitu air nira pelaku usaha sudah mempunyai masing masing pohon.

\section{d. Total Biaya Produksi}

Total biaya adalah biaya yang dikeluarkan selama proses produksi, besarnya biaya yang dikeluarkan untuk memproduksi sesuatu menentukan harga pokok dari produk yang dihasilkan. Biayabiaya yang dimaksud adalah biaya yang diperhitungkan sehubungan dengan penelitian ini, yaitu biaya tetap dan biaya variabel yang dikeluarkan yang tidak langsung mempengaruhi besarnya produk yang dihasilkan.Sedangkan biaya variabel adalah biaya yang dikeluarkan yang mempengaruhi secara langsung jumlah 
produk yang dihasilkan, adapun biaya-biaya tersebut dapat dilihat pada tabel 6 .

Tabel 4. Rata-rata Total Biaya Produksi yang Digunakan Oleh Usaha gula Aren Di Desa Buntu Pema Kecamatan Curio Kabupaten Enrekang

\begin{tabular}{|c|c|c|c|}
\hline No & $\begin{array}{c}\text { Total Biaya } \\
\text { Produksi }\end{array}$ & Jumlah & Rata-rata \\
\hline 1 & $\begin{array}{l}\text { Total Biaya } \\
\text { Tetap }\end{array}$ & 2.122 .440 & 106.122 \\
\hline 2 & $\begin{array}{l}\text { Total biaya } \\
\text { variable }\end{array}$ & 465.000 & 23.250 \\
\hline Jum & & 2.587 .440 & 129.372 \\
\hline
\end{tabular}

Tabel 4. menunjukan jumlah rata-rata biaya yang dikeluarkan secara keseluruhan usaha responden di Desa Buntu Pema Kecamatan Curio Kabupaten Enrekang dengan biaya variabel Rp. 465.000 dan biaya tetap Rp. 2.122.440 sama dengan Rp. 2.587.440dengan biaya rata-rata dikeluarkan usaha responden sebesar Rp. 129.372.

\section{Analisis Kelayakan Usaha}

Kelayakan merupakan penilaian yang menyeluruh untuk menilai keberhasilan suatu proyek, dan studi kelayakan proyek mempunyai tujuan untuk menghindari keterlanjuran penanaman modal yang terlalu besar untuk kengiatan yang ternyata tidak menguntungkan.Studi kelayakan proyek atau bisnis merupakan suatu kengiatan mengevaluasi, menganalisis, dan menilai layak atau tidak suatu proyek bisnis dijalankan (Jumingan, 2009). Terkait analisis data tersebut dapat digunakan rumus sebagai berikut:

\section{a. Biaya Usaha gula aren}

Total Biaya Variabel = Rp. 465.000

Total Biaya Tetap $=$ Rp. 2.122.440

Rumus : $\mathrm{TC}=\mathrm{TVC}+\mathrm{TFC}$

$$
=\text { Rp. } 465.000+\text { Rp. } 2 \cdot 122 \cdot 440
$$

$\mathrm{TC}=\mathrm{Rp} \cdot 2.587 .440$

Penerimaan Usaha Gula Aren Harga Rata-

rata $=$ Rp. 40.000

Jumlah Penjualan $=128$ Unit

Rumus : TR $=\mathrm{P} \times \mathrm{Q}$

$=$ Rp. $40.000 \times 128$ Unit

$\mathrm{TR}=\mathrm{Rp} \cdot 5.120 .000$

b. Pendapatan Usaha Gula Aren

Total penerimaan $=$ Rp. 5.120 .000

Total Biaya = Rp. 2.587 .440

Rumus : $\pi=\mathrm{TR}-\mathrm{TC}$

$=\mathrm{Rp} 5.120 .000-\mathrm{Rp} . .2 .587 .440$

$$
\pi=\text { Rp. } 2.532 .560
$$

\section{c. Uji Kelayakan}

Penerimaan $=$ Rp. 5.120 .000

Total Biaya $=$ Rp. 2.587 .440

$\frac{5.120 .000}{2.587 .440}$

Rumus

$: \mathrm{R} / \mathrm{C}=\frac{T R}{T C}$

$\mathrm{R} / \mathrm{C}=1.98$

Nilai R/C Ratio yang diperoleh sebesar Rp. 1.98 berdasarkan kriteria, apabila R/C Ratio >1, maka usaha tersebut layak untuk dikembangkan atau diusahakan, jadi setiap pengeluaran Rp. 1,- akan diperoleh penerimaan sebesar 1.98,-- dengan 
melihat jumlah usaha gula aren dapat dikatakan usaha tersebut menguntungkan secara ekonomis dan layak untuk diusahakan.

\section{Analisis Pendapatan Usaha Gula Aren}

Pembahasan dalam penelitian ini adalah fokus membahas mengenai analisis pendapatan usaha gula aren di Desa Buntu Pema Kecamatan Curio Kabupaten Enrekang. Dari hasil penelitian diketahui bahwa usaha gula aren di Desa Buntu Pema layak untuk dikembangkan. Karena dari hasil analisis telah diolah dan dikembangkan didapatkan perbandingan dari $\mathrm{R} / \mathrm{C}$ adalah 1.98 yang artinya setiap pengeluaran 1 rupiah makan maka akan memberikan penerimaan sebesar 1.98 . Dengan demikian hasil analisis R/C Ratio Lebih besar dari satu. Sehingga dapat disimpulkan bahwa usaha gula aren di Desa Buntu Pema Kecamatan Curio Kabupaten Enrekang memiliki prospek budidaya yang layak untuk dikembangkan. Hal ini sejalan dengan dengan penelitian Widayanti (2009) yang menhasilkan R/C Ratio 2.17 dan mengatakan bahwa apabila lebih besar dari 1 (satu) maka layak untuk dikembangkan sehingga budi daya gula aren sangat menguntungkan dan layak untuk dikembangkan. Untuk mengetahui berapa besar pendapatan dari usaha memproduksi gula aren dapat dilakukn dengan menganalisis beberapa komponen diantaranya adalah harga, biaya produksi dan hasil produksi.

\section{a. Harga Jual}

Harga adalah nilai tukar barang atau jasa yang menunjukkan tinggi rendahnya nilai atau kualitas suatu barang dan jasa. Di Desa Buntu Pema harga gula aren bervariasi tergantung dari hasil cetakan dari gula aren tersebut. Rata-rata harga gula aren adalah Rp. 40.000 per unit. harga jual gula aren di Desa Buntu Pema adalah salah satu fenomena yang ditemui di lapangan Dalam dunia bisnis khususnya perusahaan dagang menjadi sebuah kewajiban baik perusahaan untuk menentukan harga pokok produk agar dapat menghitung jumlah (biaya) pengorbanan yang diperlukan untuk menghasilkan produk (Horngren dkk, 2005). Produsen menentukan harga jual sebesar Rp.40.000,- per unit yang dinilai cukup tinggi jika dibandingkan dengan gula sejenis, tentu ini yang menjadi problematika di masyarakat akan ketidaktahuan terhadap perhitungan harga pokok produksi, harga jual, dan profitabilitas. Harga tersebut menjadi relevan apabila kita tahu akan proses produksi yang dipengaruhi faktor magis dan spiritual. Penulis menerangkan lebih rinci mengenai ketidaktahuan masyarakat selaku produsen terhadap harga pokok produksi yang berkaitan langsung 
dengan harga jual dan profitabilitas dengan menggunakan analisis terhadap penetapan harga (Jurnal Riset Ekonomi, Manajemen, Bisnis dan Akuntansi : 2015) berdasarkan biaya (Cost Based Pricing), strategi yang digunakan adalah Harga Biaya Plus (Cost Push Pricing Method) yaitu penetapan harga produk dengan menghitung jumlah biaya produksi, kemudian tambahkan dengan nilai keuntungan yang diinginkan (disebut juga margin).

\section{b. Biaya Produksi}

Biaya produksi adalah biaya keseluruhan biaya yang dikeluarkan untuk menhasilkan sejumlah produk yang dijual. Berdasaran perilakunya dalam bereaksi terhadap perubahan volume produksi suatu produk tertentu. Maka biaya dikelompokkan menjadi biaya variable dan biaya tetap, biaya variable adala biaya yang akan selalu berubah sejalan dengan perubahan tingkat aktivitas. Biaya tetap adalah biaya yabf relative tidak berubah walaupun terjadi perubahan tingkatan aktivitas dalam batas tertentu. Adapaun biaya tetap yang dikeluarkan oleh produsen gula aren di Desa Buntu Pema terdiri dari untuk pembelian wajan, ember, spatula, cetakan dan dapur kayu yang jika ditotalkan semua sekitar Rp 1.612.440 dan biaya tetap pajak yaitu $\mathrm{Rp}$ 510.000. sedangkan biaya variable yaitu biaya pembelian bahan dasar pmbuatan gula aren yaitu kemiri sebesar Rp 465.000.

Jumlah biaya variable tersebut merupakan jumlah biaya yang tidak memperhitungkn biaya bahan baku karena bahan baku pembuata gula aren yang berupa nira aren diambil dai lahan kebun prousen sendiri, begitupula dengan biaya pembelian kayu bakar tersebut kebanyakan produsen mengambil kayu bakar di kebunnya sendiri.

Total biaya adalah keseluruhan biaya yang dikeluarkaan untuk memproduksi suatu barang. Berdasarkan hasil analisis dapat dilihat bahwa total biaya produksi untuk pembuatan gula aren tidak besar, dimana total untuk pembuatan gula aren yang dikeluarkan produsen gula aren di desa buntu pema sebesar Rp.2.587.440.

\section{c. Hasil Produksi}

Hasil produksi gula aren di Desa Buntu Pema bervariasi tergantu pada jumla air nira hasil sadapan. Pohon aren yang produktif dapat menhasilkan air nira maksimal 35 liter perhari dan minimal lima liter perhari. Lima liter nira dapat dapat diolah menjadi satu buah gula aren. Jika hasil sadapannya maksimal mencapai 35 liter maka produsen bisa memproduksi gula aren sebanyak 7 unit gula aren. Semakin banyak memproduksi gula aren maka tingkat penerimaan produsen semakin 
meningkat dan berdampak pada pendapatan produsen bertambah

Penerimaan responden dalam usaha pembuatan gula aren di Desa Buntu Pema Kecematan Curio Kabupaten Enrekang adalah Rp. 5.120 .000 dan pendapatan sebesar Rp. 2.532.560. hal ini sejalan dengan penelitian Karmison Defri (2010) yang menyatakan bahwa harga produksi sangatlah mempengaruhi penerimaan suatu usaha gula aren, karena semakin besar harga dipasaran maka akan lebih besar pendapatan usaha gula aren, sehingga perlu diketahui sebelum melakukan suatu proses usaha gula aren maka lebih dahulu diketahui harga dipasaran agar mendapatkan keuntungan yang lebih besar.

Gula aren mempunyai kekhasan, yakni mudah larut dan mempunyai aroma yang khas, apabila dibanding dengan gula tebu.Oleh sebab itu, gula aren banyak digunakan dalam pembuatan berbagai macam makanan terutama kue-kue. Bahan dasar gula aren berasal dari nira yang masih segar, memiliki rasa yang manis, tidak berwarna dan memiliki pH 6-7. Gula aren diperoleh dengan cara memasak nira segar hasil sadapan sampai kental dan berwarna coklat kemerahan. Dalam proses pemasakan selalu dilakukan pengadukan untuk mencegah agar nira tidak meluap (Anonimus, 2013). Di kota Tomohon, petani pengolah gula aren dalam mencegah agar nira tidak meluap selain melakukan pengadukan mereka juga memberi sedikit minyak kelapa. Setelah nira menjadi kental, selanjutnya diangkat dan siap dituangkan ke dalam cetakan.

Hal ini juga didukung oleh penelitian Makarennu, dkk (2018) hasil penelitiannya mengungkap bahwa usaha penggorengan gula aren di kecamtan cendrana sebesar Rp. 286.860.375 dan rata-rata pendapatan setiap petani sebesar Rp. 9.562.012 per tahun. Hal ini didukung oleh penelitian yang dilakukan oleh Yanti (2014) hasil penelitiannya mengungkap bahwa rata-rata pendapatan bersih atau keuntungan diperoleh oleh pengrajin gula aren di desa tulo'a yaitu sebesar Rp 1.395.684/ bulan dengan nilai $\mathrm{R} / \mathrm{C}$ ratio sebesar 2,12. Berdasarkan $\mathrm{R} / \mathrm{C}$ ratio lebih dari satu berarti dapat dikatan usaha penrajin gula aren di desa Tulo'a menguntungkn dan layak untuk diusahakan. Selanjutnya penelitian yang dilakukan oleh Erfelien dkk (2017) hasil penelitiannya mengungkap bahwa Total penerimaan seluruh pengolah gula aren di Dusun Kalatin, sebesar Rp.3.310.000/hari. Dari jumlah penerimaan yang diperoleh seluruh pengolah gula aren dengan biaya yang dikeluarkan sebesar Rp.2.411.902 maka, diperoleh keuntungan oleh 18 orang pengolah yaitu Rp.898.098/hari jika tidak 
dihitung biaya bahan baku, maka setiap pengolah memperoleh keuntungan Rp.49.898/hari. Namun, jika dihitung biaya bahan baku maka kerugian yang dialami oleh seluruh pengolah gula aren yaitu sebesar Rp.-2.903.902/hari dengan biaya yang dikeluarkan yaitu Rp.6.213.902 dan setiap pengolah mengalami kerugian sebesar Rp.- 161.327/hari.

\section{KESIMPULAN DAN SARAN}

Pendapatan gula aren di Daerah Buntu Pema adalah RpRp. . 2.532.560 selama selama satu kali produksi.Hasil rata-rata pendapatan petani responden cukup besar untuk digunakan menutupi kegutuhan hidup dan menunjang keuangan rumah tangga petani dikala tepuruknya harga komoditi pertanian utama petani sampel di daerah penelitian.Nilai revenue cost ratio (R/C49ratio) adalah sebesar 1,98 menunjukkan bahwa $\mathrm{R} / \mathrm{C}>1$ berarti usaha layak untuk dijalankan. Atau denga kata lain pendapatan lebih besar dari total biaya yang dikeluarkan maka usaha gula aren di Desa Buntu Pema di Kecamatan Curio Kabupaten Enrekang layak untuk di jalankan.

Untuk meningkatkan pendapatan usaha gula aren sebaiknya dicetak dalam bentuk yang beragam agar konsumen lebih tertarik. Sebaiknya juga di jual langsung kepada konsumen dari pada pedangan pengumpul karena jika di jual langsung kepada konsumen maka keuntungan yang didapatkan lebih banyak.Diharapkan dari pemerintah untuk mengadakan kebijakan harga atau menetapkan harga dimana kebijaksanaan ini diperlukan untuk menjaga agar harga gula aren tidak terjadi fluktuasi, sehingga pembuatan gula aren bersemangat dalam mengolah lahan pertanian yang mengakibat meningkatnya taraf masyarakat di desa pema kecamatan curio kabupaten enrekang. Jika tingkat kesejahteraan usaha pembuatan gula aren meningkat tidak menuntut kemungkinan akan diikuti oleh pembangunan ekonomi yang lebih baik dan tingkat kemiskinan berkurang.

\section{DAFTAR PUSTAKA}

Aurand, L. W ., A . E. woods,, dan M.R. Wells. 1987. Food Composition and Analysis. An Avi Book. New York. Reinhold Company.

Arikunto, S. 2002. Metodologi Penelitian Suatu Pendekatan Proposal.Jakarta : PT. Rineka Cipta.

Erfelien dkk.2017.analisis pendapatan usaha gula aren di dusun kalatin kecamatan ratahan kabupaten minahasa tengara. Jurnal Agri-Sosio Ekonomi Unsrat, ISSN 1907-4298, Volumen13 Nomor 3A, November 2017:39-50

Gilarso, 2001 : Pengantar Ilmu Ekonomi, Kanisius, Yogyakarta.

Husain Umar. (2005), Metode Penelitian Untuk Tesis dan Bisnis, Jakarta : Grafindo Persada.

Harahap, Sofyan Syafari. Drs, 2007. Analisis Kritis Atas Laporan Keuangan, Cetakan ke-7. Jakarta : PT Raja Grafindo Persada. 
J. Supranto, 1998, STATISTIK (Teori dan Aplikasi) Edisi Kelima, Erlangga, Jakarta.

Jumingan.2009 . Analisis Laporan Keuangan. Jakarta : Bumi Aksara.

Kristianingrum, Susila. 2009. Analisis Nutrisi Dalam Gula Aren. Kegiatan PPM Teknologi Pembuatan Gula Aneka Rasa. Jurusan Pendidikan Kimia Fakultas Teknologi Pertanian. IPB. Bogor

Makarennu, dkk (2018).Analysis pendapatan usaha gula aren pada mayarakat yang tertinggal di dalam di sekitar hutan.Jurnal perennial. 2018 Vol. 14 No.2:61-65 ISSN: 14127784.tersedia online http:// journal.unhas.ac.id/index.php/perenni al

Mubyarto.1995 Pengantar Ekonomi Pertanian.Jakarta : Edisi KeTiga.LP3S

Mugiono,dkk. 2014 Analisis Pendapatan Usaha Gula Merah Kelapa Di Desa Medono Kecamatan Kaliwiro Kabupaten Wonosogo. Universitas Wahid Hasim. Wono Sogo

Purwanti, O.S 2013. Analisis Faktor-Faktor Resiko Terjadinya Ulkus Kaki Pada Pasien Diabetes Melletus di RSUD DR.Moewardi Surakarta, Prosiding Seminar Ilmiah Nasional, ISSNN: 2338-2694,

http://journal.ui.ac.id/index.php/jkepi/article /view/2763, diakses tanggal 3 Februari2014.

Rika Sylvia,dkk. 2018 Analisis Pendapatan Usaha Gula Aren Desa Tanjung Saloka Utara Kecamatan Pulau Laut Selatan Kabupaten Kota Baru. Kota Baru

Sale, yanti. 2014. analisis pendapatan gula aren di desa Tulo'a kecamatan Bulango utara kabupaten Bone.jurnal perpektif pembiayaan dan pembangunan daerah,Vol.1 No.4,2014
Soekartawi, 2001. Pengantar Agroindustri. Edisi 1.Jakarta : cetakan 2. PT Raja Grafindo Persada.Hal 152.

Suliyanto. 2010. Studi Kelayakan Bisnis Pendekataan Praktis. Andi Offset. Yogyakarta.

Skousen, Stice, 2001. Akuntansi Keuangan Menengah. Edisi Kesembilan, Jilid Satu, Terjemahan. Salemba Empat, Jakarta.

Soekartawi. 1995. Analisis Usahatani. Universitas Indonesia Press. Jakarta. 